\title{
Tweeting and Click: Internet and New Social Movement in Indonesia
}

\author{
Ahmad Ismail \\ Faculty of Social and Political Sciences, \\ Hasanudin University \\ Makassar, Indonesia. \\ ahmadismailguntur@gmail.com
}

\begin{abstract}
Social movement happened intensively since the last decade which its uniqueness is done by internet technology. What happened actually is not just about the innovation of internet technology 'itself' - furthermore, it's about the civil activity. "Gerakan Akademi Berbagi" which based their movement in internet-social media specifically- is the case for this thesis with the use of connective ethnography method for 5 months of research. The result described that "Gerakan Akademi Berbagi" is one of wide manifestation that raised the civil society by combining online and offline which contributes context, validation, and bond in participation for its volunteers that gave birth to what it called as 'online social movements'.
\end{abstract} Media.

Keywords-Social Movement, Civil Society, Internet, Social

\section{INTRODUCTION: NEW SOCIAL MOVEMENTS ADOPT INTERNET}

Just two days after the 2004 tsunami devastated Aceh, volunteers from Air Putih managed to restore communications and provide internet connection is lost in the tsunami. Without these two aspects: communication and internet connection, humanitarian assistance work in helping victims can not be done quickly and the maximum [10]. A similar story happened when the volcano erupted in Yogyakarta in October 2010 and claimed the lives of hundreds of people and forced the entire population living in the region to evacuate, volunteers Jalinmerapi utilize the internet and social media to mobilize volunteers and distribute the aid.

In a different case, but a similar spirit, the use of the Internet has been to public attention in Indonesia (maybe even the world) in the case of Prita Mulyasari who was convicted of defamation Omni International Hospital and the criminalization of the two leaders of the Corruption Eradication Commission (KPK) Bibit - Chandra. When social media such as facebook and twitter is used as the preferred means to mobilize community action Indonesia. In the context of Indonesia, some of these phenomena are examples that reinforce the idea of "new social movements", the organization and its scale is characterized by the use of social media. [10].

For the case of other countries that make use of the internet to do the movement is the Egypt State. A movement will be recorded by history as a first mass movement which was facilitated by social networking twitter and facebook. The unique design of the mass mobilization of the participants of the demonstrations in Egypt that the mass mobilization can be done so quickly and organized as they take advantage of social media twitter and facebook, as well as methods of communication via cell phone (Short massege Service).
Just as happened in the United States about the movement Anti-Wall Street. The Accopy Wall Street movement has spread in less than three weeks, from a small group of demonstrators from Manhattan to a glass of age and various states in the United States. This movement starts from the launch on twitter on July 13, 2011. The movement is the result of a successful mobilization through twitter performed with short no more than three weeks.

Background stories above show that this phenomenon is not just about technological innovation internet and social media. But this is about the work civil society groups and organized communities that adopt Internet technology. The technology in this perspective, play a supporting role - serving the needs of communities of civil society in achieving their goals. For example, as happened in the state of Egypt how civil society to use the Internet, especially social media facebook and twitter to mobilize the masses to overthrow the authoritarian regime of Husni Mubarok.

This study did not focus on civil society groups as a separate unit; This research tries to build an understanding of the ways used by organizations and groups - Akademi Berbagi - the involvement of civil society in a "real" and a "virtual" in innovating through the use of new media, which in turn shape the dynamics of civic engagement towards the movement for social change.

Referring to research carried out by [4] on online greenpeace activist movement, he stated that what is done in its activities can be grouped into symbolic politics and information politics. Because the mass mobilization carried out by Greenpeace online activist movement merely symbolic resistance such as petitions and letters to the provision of policy makers rather than giving a real resistance such as demonstrations in the street. Form of movement in the form of distributing information on conservation or environmental damage.

Same thing with research by [10] about the birth of what he described as a "one-click activism". It has also become a topic in the portal Detik.com "Beware of Birth one click activism" where it is questionable that "... Lest people think just by pressing a button 'like' on facebook, he felt able to 'change the world', with millions of people are doing the same thing. Whereas the realization of such activity is only done a handful of people. This is what is feared in a civic activism through social media in Indonesia. Birth motion one click, or 'one-click activism' would be useless without the realization of the real ...." 
Seeing this, I then focused this study on a case of the Gerakan Akademi Berbagi "Academy Sharing Movement" who adopt the Internet in conducting social movements. Is Gerakan Akademi Berbagi is a portion of a click aktivism or even exceed what [11] refer to as click aktivism ?. This article will explain empirically how the civil society in the social movement by adopting the internet that is twitter, facebook and blogs.

\section{METHOD}

The researchers noted that an anthropologist's reluctance to embrace the study of the internet where people get a new challenge with the struggle of the world of technology [12] [18]. But in the reluctance, some anthropologists try to do research on the internet and in assessing the cyberspace community. Anthropology as a discipline, it is possible to assess studies online communities [3] [18]. [1] emphasizes that the internet forcing anthropologists to rethink the research procedure. [3] has been touted that the internet as a new domain' in the study of anthropology:

"The study of cyberculture is particularly concerned with the cultural constructions and reconstructions on which the new technologies are based and which they in turn help to shape...any technology represents a cultural invention, in the sense that it brings forth a world; it emerges out of particular cultural conditions and in turn helps to create new ones."

Previously, ethnographers have long traveled across some rules because they must work to understand the life experiences of others who are limited will be space and time (See [6] [17] [5]). Furthermore, the limited body of research on space and time in ethnographic methods, encourage the development of research methods have been traveling in the virtual space (see [3] [14] [8] [2]), and have found some of the challenges and the way in which researchers can learn about the community and documented in a work ethnography without the researcher having to meet face to face. An Ethnography Connective approach, is a mixture of ethnographic methods which would finite physical space as a base with a virtual world to capture life experience embodied a member of the online community when they move across multiple social spaces of their lives.

Practices of social movement is divided into two parts, namely (1) the physical space is considered as an offline context and, (2) the virtual space is considered as an online context. Ethnographic research is often limited field-based physical space (see [6] [17] [5]). But the approach Connective Ethnography, allowing it to explore and are not bound by space and time [12]. In this way, the establishment of a culture that is produced through social practices as they travel across the physical space and virtual space, moving beyond the traditional understanding of the geographical boundaries to focus on ways in which the cultural context is constructed discursively [12].

\section{RESEARCH FINDINGS \& DISCUSSION}

1. Combination Between Social Movements and Social Media

Development of Internet technology, especially in the use of social media penetration in Indonesia had a significant impact on the dynamics of civil society, to social movements
[10]. Looking at the case Gerakan Akademi Berbagi with point of view as a social movement, it needs to be emphasized is that the movement is in the category of what Singh and Tourrine call the New Social Movements (new social movements). Within the framework of [15], a social movement is divided into two categories, namely the old social movements and new social movements.

Tourrine make progress by formulating the concept of "Beyond Social Movements". Changes to the basic concept of the traditional class-based social movements which are old or classic social movement towards the concept of non-class social movement is new and contemporary. Changes in society from modernism to postmodernism, from industrialism to post-industrialism and materialism to post-materialism on the one hand, and the widening gap between the state and civil society, on the other hand, it displays a new form of society. In the context of today's contemporary, that as long as the role of the state to citizens and civil society is still a concern, then the country will still be barren and dull in solving problems in the country. However, the state will be alive when he acted appropriately, in accordance with its demands and community control. Increasing the state's right to enter the life of citizens in general to penetrate all aspects of public and private life of citizens, in terms of biology, psychology, economics, ethics, information and morality is a new phenomenon which refers to the natural emergence of contemporary forms of society. The new form of this society defines itself as a type of 'new' social movements.

The purpose and values of the new social movements an essentially universal. Their actions were directed to defend and protect the essence of the human condition for the future a better life [16]. Unlike the old social movements, new social movement is no more withdrawal in ideological discourse that is shouting anti-capitalism, the revolution of classes and class struggle, even the new social movements are not keen on the idea of revolution and overthrow the system of government in a revolutionary way. Contemporary movement in general do not support the potential emergence of "peasant revolt" [13] and "agrarian reform" [9].

Such as what is defined about the new social movements that are non-materialistic movement and non-movement classes, Gerakan Akademi Berbagi that grew out of the principle of sharing knowledge for free. Gerakan Akademi Berbagi was originally not in the organization well, but tasted a positive impact for the community, then the movement is then managed in a modern way (consciously) as an absolute requirement of new social movements.

It is interested from the Gerakan Akademi Berbagi is, where the civil society, to social movements also involve the internet, especially social media - twitter and facebook - in doing movements. There are two forms of how this movement spreads so quickly that within a short period of time this movement has spread almost throughout Indonesia, even abroad. The first, which relies on a network of friends, where the actor of Gerakan Akademi Berbagi in Jakarta contacted friends in another city to host the Gerakan Akademi Berbagi in the city. Secondly, with some communities or people accidentally discovered Gerakan Akademi Berbagi on social media and take the initiative to open up the movement in the city. It can be seen that, on the one hand, in performing the movement, the power of personal networks among actors 
mover determines how big and fast the movement can be expanded to various areas. On the other hand, the use of social media in conducting social movements also have a significant impact in socializing of Gerakan Akademi Berbagi.

In Indonesia, some cases can prove that besides of Gerakan Akademi Berbagi growing on twitter, there is also a movement before that is Coin A Chance, which occurs in the case of Prita, the movement "Cicak vs Buaya" that developed in facebook until the site wikileaks leaked confidential documents US troops and many countries including Indonesia. Wikileaks do social movements on the transparency of information as a right of all people. This is the point that marks Turning the Internet, particularly social media, is very influential even be able to drive the issues in the world.

The reason the internet, especially the use of social media -twitter and facebook- can be used as a social movement even as a pressure group. First, the advent of the era of group consciousness public increasingly attentive adaptive with advances in internet technology is mainly related to the virtual world. According to statistics, Facebook users in Indonesia entered the top 10 in the world and the 3rd largest and twitter users top 20 in the world and the 5th largest in which most users are well Education. Second, the existence of consciousness to interact, exchange issues can the formation of consciousness to split. Thirdly, the Internet is one medium that is free from domination, efficient and effective. Fourth, public awareness to perform its function as government control.

Internet - twitter and facebook - has become one of the tools of activism; Internet can facilitate a person being an activist; Internet can be used to manage support for an activism. This can all lead to greater public participation will be a time bomb ready to explode and strengthening democracy in Indonesia by giving additional powers to the people, especially when the authorities do not want to hear the people. Thus, from the presence of social media, it can be concluded that there has emerged a new movement, a new model that I call the "Online Social Movements".

\section{Form of Social Technology: Aktivisme Online}

Since the last decade, the use of social media is increasing significantly. This proved of internet usage data released by APJII (Indonesian Internet Providers Association) in 2010 that the use of the Internet rose sharply between 1998 s.d 2010. Until the year 2011 Internet users increased sharply $45,000,000$ million users. However, the use of the Internet penetrated on the use of social media applications such as Facebook and Twitter in particular. facebook and twitter social media is the most widely gandrungi by the people of Indonesia. Based on data in Indonesia, including the second largest in the world, which reached 43,523,740 million users, while Twitter in early 2012, entered into 5 in the world's largest, which reached 19.5 million users. This proves related to public space that the community now longed for a public space that can accommodate the interests of both of these groups or individuals and are embodied in the presence of social media, especially Facebook and twitter.

With so many social media users in Indonesia, then there is an opportunity to do online activities that can provide benefits to civil society's longing for a neutral space and do not have commercial pressures. Based on field research I found, the Gerakan Akademi Berbagi is born because it is considered a public space that is like a television, cafes, and other rooms have alignments and unconsciously turn off the critical sense of society. Eg television should provide impartial information and education, but in reality to see on the television screen just give treat frontal, rough, a lot of violence in the paint, and a few are displaying shades of peace in the republic.

It is then used as internet public spaces that are considered neutral and have no particular tendency interventions and [2] called the social arena. Freedom of speech and expression on the Internet, especially on social media marked with the renaissance of civil society in building and criticize government policies and development in the republic.

Various cases in Indonesia has involved the contribution of civil society to criticize and even to influence the decisions taken by the institutions of the judiciary. such as the case of Prita Mulyasari and Seed Chanda. However, based on a case study, namely the Gerakan Akademi Berbagi is also one social formation of the media to social movements. Gerakan Akademi Berbagi, who was born in 2010 from the twitter users who now became a national movement in 33 cities spread made through social media, namely Twitter.

It is then complete research [10] is one of the conclusions of the "click aktivism vs no activism". I think a very interesting conclusion from Nugroho, are:

".....This is important because there is a wide gap between clicking the button 'Like' or 'Attending' in a Facebook page or invitation for a rally or public meeting, and spending time and effort to really join the rally or the meeting - be it on a hot sunny day, or a wet rainy one. Similarly, by clicking 'Forward' after reading a moving or touching email pledging for participation or donation, people can feel they have done something. Indeed, they have-forwarding the email. But there is a huge difference between forwarding an email and directly participating in an event, or donating goods or money. In other words, we have to be aware of the distinction between real engagement and what we term here 'click activism' [10].

Phenomena click aktivism give a lot of criticism for the users of social media, especially in Indonesia, it also became the topic of discussion in the portal Detik.com about "Beware of Birth One Click Activism", in such portals questioned about "click activism" "... Lest people think just by pressing a button 'like' on Facebook, he felt able to 'change the world', with millions of people who do the same thing. Whereas the realization of such activity is only done a handful of people. This is what is feared in a civic activism through social media in Indonesia. Birth of 'one click activism' would be useless without the realization of the real movement.... "1

Therefore, one-click activism is considered a contradiction with activism involving themselves in "real". Which then becomes the question of whether the click aktivism have equal weight with activism involving themselves in real. Despite the presence in the real world is important in a digital movement, provide validation and context, tying the participation rate of more than followers, not 
less also value the contribution of the click Activists who have graced a movement, either as followers and as a fan page facebook and twitter. Not all of us have the time to attend a show of support, but in support of digital good with follow, likes, retweets, invites, email, SMS, BBM is not lacking in value and not lower position.

However, the Gerakan Akademi Berbagi not only do the "click aktivism" but a combination of online-offline in doing social movements provide context, validation and binding participation of more than volunteers across Indonesia.

\section{Movement is Considered Quasi?}

Why then movement on the Internet is considered quasi ?. Based on field data, that social movements are done on the Internet, especially social media does not have a significant impact on the change in accordance with the mission movement. But after seeing some of the actions of civil society in adopting social media to pressure or movement gives some implications for the real world then awareness of the quasi-social movement on the Internet began to fade. However, it is not a solid foundation to see whether the movement on the Internet, especially social media can be considered false or an illusion or not.

In the case of this study, the Gerakan Akademi Berbagi were so popular in the social media, especially twitter, was not directly proportional to the popularity that exist in the real world. This was evident when some activists Akademi Berbagi an audience with some students at leading universities in Indonesia, was of 500 students, all of them do not know the Gerakan Akademi Berbagi when almost all students have a twitter account.

It is then I regard as false movement or an illusion Online communities do social movements. But after the Academy Share on covered by various media mainstrem as some national Media such as television, newspapers, magazines discussion of the Gerakan Akademi Berbagi, then slowly movement is known and is always in search of its class existence which opened in every town there. It was evident after at liput by private television, some activists in other cities.

On the other hand, movements or activism that is done in the digital world is considered only an activism that does not have anything on the context of the real conditions in the real world. Just have an online context and is not binding and validate the movement in the context of what is done offline so that just a false movement. However, in the case of the Gerakan Akademi Berbagi research, this movement has the offline realm so that online social movement Akademi Berbagi provides its own context and provide binding the movement on a particular context in the context of education in Indonesia.

This thing then happened dichotomy between "reality" and "virtual". What happens in the virtual world tendency, or sometimes not directly proportional to what is happening in the real world or reality. The case of Prita Mulyasari with coins for Pritchard on Facebook, Bibit-Chandra with "Cicak vs. Buaya" is also on facebook, and Gerakan Akademi Berbagi on facebook and twitter, each has a movement offline and so have the context of events and the validity of that movement is not merely apparent or just an illusion.
However, in view of this dichotomy, [7] is very cautious in view of 'reality' and 'virtual', can be seen from the excerpts conversation below where Sherie difficult to separate between online and offline context:

"Sherie refused the distinction once more...In the same way, I asked Sherie how "real" her experiences in the Internet were. She replied, "how real are experiences off the Internet? they're equivalent. they're not the same, but I'm still emotionally and intellectually invested in them, physically too even." "What do you mean?" I asked. "i get as emotionally upset and physically stressed over a flame war as $i$ do over a conflict that i'm a part of." Again, Sherie rejected my efforts to separate online and offline experiences into real/not real distinctions... Sherie seemed to focus on the fact that selves or relationships exist, regardless of the context.

It can be seen that what is happening to Sherie is the fact that the separation itself with the online experience hard he split, even a unity that integrates and does not have boundaries between online and offline. Therefore, the difference between reality and virtual in many ways just as valid as that created by community members themselves. [11] presents a more cautious of the dichotomy between "reality" and "virtual". [11] questioned the views of online communication that gives a great appreciation of the knowledge created by the virtual space with contrasting knowledge being created in the space of knowledge with territorial boundaries set out in the geographical space. He argues that:

"How is it, we would want to ask, that the 'new universe' of knowledge has come to seem more 'real' and meaningful than other - embodied and situated-kinds of knowing and engaging with the world?".

In the virtual world in view of Robbins and Webster is, "... space exiled, who had lost touch with the reality of the world - and consequently the function of the belief that a world where most of us still want to live no longer has any reality." Rheingold description of experience seems to be against Robins and Webster of online group interaction as a social aggregation of the economy. it is obvious that Robbins and Webster had been demolished by the Rheingold considered this definition ignores the nuance differences and strong emotions in the community or online community.

Internet is a phenomenon of the interaction of technology and culture [2]; and the social and cultural impact in the development of online communities related to the concept of empowerment. Empowerment will not occur in a vacuum of social bonds based only on "common interests". The social movement is about empowerment, build consensus, establish common values and spread them in the movement to support change for the better. Empowerment encourage social movement that aims to build a collective identity.

\section{CONCLUSION}

First, I conclude that this study complements the results [10] about what he described as a click activism. Phenomena click activism which becomes findings Nugroho has been a debate among observers of social media, where the result of how activism done on the internet, without involving 
themselves in "real", activism is regarded as activism apparent, it is also a discussion in the AFP about the 'birth of click activism'. Similarly [4], which considers that the social movements are done on the internet just performs assessments, disseminate information and have no real movement towards a vision that is done, only limited build a discourse built on the internet. From these results, the social movement is done on the internet is not just a mere click activism, or simply to share information, but social movements on the internet could exceed "beyond" it. On condition that the movement has an attachment context with the real world, social movements on the Internet does not escape from the context of offline 'real', to feel like a movement in the wake of validity or synchronization between online and offline.

Second, the social movement by adopting Internet technology has given a new concept of movement I call the 'Online Social Movements'. Although it is called with the keyword 'online' as Online Social Movement, the movement is not only done in the internet space, but the context of the offline or real space is also a portion importance of online social movements in order to provide context, validation and attachments participation in conducting social movements.

Third, the form of online social movement is a selection of contemporary society is currently doing activism. Civil society has played an important role as people in charge and doing social movements criticize the government by adopting social media, namely the Internet. In this case, the Gerakan Akademi Berbagi has become one of the manifestations of the rise of civil society, to social movements born out of social media. Like what is called by [18] rediscovery of civil society through the internet.

\section{REFERENCES}

[1] Axel, i. K. 2004. The Context of Diaspora. Cultural Anthropology vol. 19: 26-60.

[2] Bell, david., 2001. An Introduction to Cyberculture. Routledge. Taylor \& Francis Group. London and new York.

[3] Escobar, Arturo; Hess,David; Licha, Isabel; Sibley, Will; Strathern, Marilyn; Sutz, Judith. 1994. Welcome to Cyberia: Notes on the Anthropology of Cyberculture [and Comments and Reply]. Current Anthropology, Vol. 35, No. 3 (Jun., 1994), pp. 211-231 di akses pada tanggal 28 februari 2011 www.jstor.org

[4] Faisal, Moch. 2008. Dari Anarchic Cyber Space menjadi Transnational Public Sphere: Membaca Relasi antara Cyberspace dan Civil Society di Era Postmodern. Diterbitkan oleh Global Jurnal Politik Internasional vol. 9 No.2 Desember 2007 - Mei 2008. Departemen Ilmu HI. FISIP Universitas Indonesia.

[5] Geertz, C. 1973. The interpretation of culture. Selected Essay by Geertz. Publisher. Basic Books. Inc.

[6] Malinowski, Bronislaw. 1932. The Western Pasific. An account of Native Enterprise and Adventure in the Archipelagoes of Melanesian New Guinie. New York: E.P. Dutton \& Co.

[7] Markham, A. N. 1998. Life online: researching real experience in virtual space. New York: Alta Mira Press.

[8] Miller, Daniel and Slater, Don., 2000. The internet: An Ethnographic Approach. Berg. Oxford, New York.
[9] 10. Moore, D.S. 1996. "Marxism, Culture, and Political Ecology: Environmental Struggles in Zimbabwe's Eastern Highlands." In Liberation ecologies: Environment, Development, social movement. Edited by R. Peet and M. Watts. Pp. Xie, 273 London.: New York: Routledge.

[10]Nugroho, Yanuar. 2011. @ksi Warga: Kolaborasi, demokrasi partisipatoris dan kebebasan informasi Memetakan aktivisme sipil kontemporer dan penggunaan media sosial di Indonesia. Laporan. Kolaborasi penelitian antara Manchester Institute of Innovation Research, University of Manchester dan HIVOS Regional Office Southeast Asia. Manchester dan Jakarta: MIOIR dan HIVOS.

[11]Robins, K., and F. Webster. 2002. Prospects of a Virtual Culture. Science as Culture 11:235-256.

[12] Schmier, Stephanie Anne, 2010. Our Space: Researching Literacies and Identities in and across classroom and Online spaces. Dissertation. Columbia University.

[13] Scoot, J. 2007. Senjatanya Orang-orang yang Kalah. Penerbit Yayasan Obor Indonesia.

[14] Shield, Rob., 1996. Culture of Internet: Virtual Space, Real Histories, Living Bodies. SAGE Publication.

[15] Sujadmiko, Ivan gardono. 2006. Gerakan Sosial: Wahana Civil Society bagi Demokratisasi. Darmawan Triwibowo (ed). Pustaka LP3ES Indonesia.

[16] Singh, Rajendra. 2010. Gerakan Sosial baru. Penerbit Resist Book. Yogjakarta.

[17] Turner, Victor. 1977. The Ritual Procces: Structure and Anti-Structure. Symbol, Myth and Ritual.

[18] Hajal, P. 2002. Civil Society in the Information Age. Ashgate, Hampshire. 